\title{
Soil type, microsite, and herbivory influence growth and survival of Schinus molle (Peruvian pepper tree) invading semi-arid African savanna
}

\author{
Donald M. Iponga $\cdot$ Suzanne J. Milton • \\ David M. Richardson
}

Received: 29 January 2008/ Accepted: 12 February 2008/Published online: 29 February 2008

(C) Springer Science+Business Media B.V. 2008

\begin{abstract}
Naturalization of Schinus molle (Anacardiaceae) has been observed in semi arid savanna of the Northern Cape Province of South Africa. However, with high dispersal ability, the species is expected to achieve greater densities and invade more widely. The study involved a field manipulation experiment over 14 months using a factorial block design to examine transplanted seedlings in different savanna environments. The experiments examine the effects of soil type (sandy and clay), microsite, and herbivores on seedling performance (establishment, growth and survival). Seedlings were grown in a greenhouse and individually transplanted into four treatment groups: in open grassland, under tree canopies, and with and without cages to exclude
\end{abstract}

D. M. Iponga $\cdot$ S. J. Milton

Centre for Invasion Biology, Department of Conservation Ecology \& Entomology, Stellenbosch University, Private Bag X1, Matieland 7602, South Africa e-mail: dmiponga@sun.ac.za

\section{S. J. Milton}

e-mail:sukaroo@telkomsa.net

D. M. Richardson ( $₫)$

Centre for Invasion Biology, Department of Botany and Zoology, Stellenbosch University, Private Bag X1, Matieland 7602, South Africa

e-mail: rich@sun.ac.za large herbivores (cattle and game). The same experiment was repeated in two different soil types: coarse sand and fine-textured clay soil. Results suggest that protection provided by canopies of large indigenous Acacia trees facilitates $S$. molle invasion into semiarid savanna. In the field, $S$. molle seedlings performed considerably better beneath canopies of indigenous Acacia trees than in open areas regardless of soil type. Whether exposed or protected from large herbivores, no seedlings planted in open grassland survived the first winter. Although, seedlings grew better and had higher survival rates beneath tree canopies than in the open sites, exposure to large herbivores significantly decreased heights and canopy areas of seedlings compared with those protected from large herbivores. The effect was greater on clay soil than on sandy soil. The results suggest that low temperature (frost), and possibly inter-specific competition with grasses, may limit $S$. molle seedling establishment, survival and growth away from tree canopies in semi arid savannas. Low soil nutrient status and browsing may also delay growth and development of this species. The invasive potential of $S$. molle is thus greatest on fertile soils where subcanopy microsites are present and browsing mammals are absent.

Keywords Alien plants - Biological invasions · Invasive species - Microhabitat . Interspecific interaction - Facilitation · Transplanting - Tree invasions 


\section{Introduction}

Variation in the success of particular introduced plant species can be caused by numerous environmental features, including substrate type and climatic factors. Harsh climatic conditions such as frost or drought can prevent the establishment of seedlings of species from milder climates. On the other hand, unusual weather events, such as above-average rainfall, may trigger establishment and facilitate naturalization or invasion (Richardson et al. 2000).

Success is also mediated by various biotic interactions. The availability of dispersal agents to move viable seeds to suitable microsites (Jordano and Herrera 1995; Dean and Milton 2000), the absence of superior competitors for a limiting resource (Canham 1989; Iponga et al. 2007), and limitation of damage by pathogens and predators (Hoffmann and Moran 1998) may all increase the probability of invasion or determine the spatial distribution of an invasive plant population in the landscape (Russell and Schupp 1998). One of the most important mechanisms for facilitating plant establishment in semi-arid environments is the amelioration of stressful micro-climatic conditions (Callaway 1995). In savannas, microsites beneath tree canopies are among the most favourable for the establishment of seedlings of certain trees and shrubs (Verdú and Garcia-Fayos 1996; Flores and Enrique 2003). One reason for this is that variations in ambient temperatures are buffered and relative humidity is greater in these microsites (Belsky et al. 1989; Belsky 1994). Few studies have documented facilitation of alien trees by native trees, but Milton et al. (2007) show that such facilitation can act as a potent mediator of invasion success.

Schinus molle (Anacardiaceae) is an evergreen, drought-tolerant tree native to semi-arid parts of South America. Since the 1800s it was widely planted on roadsides, in graveyards, and in gardens in South Africa as a shade tree. It has recently become naturalized at some sites in semi-arid savanna (Iponga et al. 2008). It is already considered a major invader in South Africa (Nel et al. 2004), but has the potential to expand its range considerably (Rouget et al. 2004). The species is dioecious and flowers and fruits continuously throughout the year. Female trees produce large crops of small bright pink berries in bunches on pendulous stems, and the seeds are dispersed by birds, mammals, and water (Silva et al.
2005). Where naturalized in South Africa, seedlings occur mainly beneath indigenous Acacia trees where seeds of $S$. molle and other fleshy-fruited plants are dispersed by birds (Milton et al. 2007). Such sites are also used preferentially by large herbivores seeking shade. Therefore this study specifically investigates the ways in which the following factors, individually and in concert, potentially influence establishment, growth and survival of $S$. molle seedlings in semi-arid savanna: soil type; facilitation by large Acacia tree canopies; and herbivory by large mammals. We then consider the implications of those patterns for the prediction of the invasion potential of this species in semi-arid savanna of South Africa.

\section{Methods}

Study sites

The study was carried out at Benfontein Game Farm $\left(28^{\circ} 50^{\prime} \mathrm{S} ; 24^{\circ} 50^{\prime} \mathrm{E}\right)$, an 11,300 ha property owned by De Beers Consolidated Mines and located approximately $8 \mathrm{~km}$ south-east of town of Kimberley in South Africa's Northern Cape Province. The mean annual rainfall for Kimberley is $431 \pm 127 \mathrm{~mm}$ and usually peaks in the late summer months (March and April). Precipitation is usually in the form of late afternoon thundershowers. Mean daily temperature maxima and minima range between $33^{\circ} \mathrm{C}$ and $18^{\circ} \mathrm{C}$ in January, and 19 and $3^{\circ} \mathrm{C}$ in July (South African Weather Bureau 2007), and the altitude is about $1,200 \mathrm{~m}$ above sea level.

The vegetation in the area is Kimberley Thornveld, a component of the Eastern Kalahari bushveld bioregion (Mucina et al. 2006), and consists of semiarid open savanna. Much of the farm is covered by open grassland with dwarf "karroid" shrubland surrounding a large but ephemeral pan (temporary water body). Soils at Benfontein can be divided into three types. In the north-west the substrate of the pan substrate comprises calcium carbonate (calcrete). Away from the pan to the south-east a belt of red Kalahari sand overlies the calcareous tufa. Igneous intrusions (dolerite hills) along the southern and south-western boundaries, give rise to fine-textured soil in this section of the farm (Spottiswoode 2005). Cattle (Bos indica) stocked at approximately $18 \mathrm{ha} /$ LAU (1 LAU or Large Animal Unit is equivalent to 
one head of cattle weighing $450 \mathrm{~kg}$ ) are confined to open woodland dominated by Acacia erioloba on the sandy soils at Benfontein. The remaining 8,300 ha of Benfontein, including the pan and the Acacia tortilis dominated savanna on finer-textured soils is managed as a game farm. Indigenous animals are stocked at approximately $15 \mathrm{ha} / \mathrm{LAU}$ and include springbok, Antidorcas marsupialis (ca 2,134 individuals); blesbok, Damaliscus dorcas phillipsi (115), black wildebeest, Cannochaetus gnou (253) and ostrich, Struthio camelus (259). Smaller antelope including steenbok, Raphicerus campestris, common duiker, Sylvicapra grimmia, and the mountain reedbuck, Redunca fulvorufula also occur at low densities throughout the area.

\section{Method description and sampling}

\section{Experimental design}

Seedlings of $S$. molle were germinated in a greenhouse at Stellenbosch University. Geminated seedlings were transplanted into 1,000 ml plastic bags and maintained at ambient temperatures with daily watering until they reached a height $10-15 \mathrm{~cm}$. Two hundred of these seedlings were then transported to Kimberley in March 2006 for use in transplanting experiments.

A total of $120 \mathrm{~S}$. molle seedlings were transplanted to the savanna, 60 on sandy soil, and 60 on fine soil (Table 1). As the soil types were $20 \mathrm{~km}$ apart on opposite sides of the pan, the soil-type treatments could not be interspersed. Within each of the soil types, a factorial bock design was used to examine effects of microsite and herbivory on seedling

Table 1 Allocation of Schinus molle seedlings to treatments

\begin{tabular}{lll}
\hline Treatments & Sandy soil & Fine-textured soil \\
\hline Host tree & $\begin{array}{l}\text { Acacia erioloba } \\
\text { Browser }\end{array}$ & $\begin{array}{l}\text { Acacia tortilis } \\
\text { Cattle }\end{array}$ \\
$\begin{array}{l}\text { Subcanopy (caged) } \\
\text { Subcanopy (exposed }\end{array}$ & 15 & 15 \\
$\quad 15$ & 15 \\
$\quad$ to herbivores) & & \\
Grassland (caged) & 15 & 15 \\
$\quad$ to hassland (exposed & 15 & 15 \\
$\quad$ Total & 60 & 60 \\
\hline
\end{tabular}

performance. Ten spreading Acacia erioloba trees were selected as host plants on Kalahari sand and 10 Acacia tortilis trees were selected as hosts on finetextured soil. Beneath each of these host trees, three S. molle seedlings were planted (approximately $2 \mathrm{~m}$ to the south, east and west of the host tree trunk). Plantings of three $S$. molle seedlings were made in open grassland beyond the canopies of each of the 20 host trees. Individual cages were placed around 60 seedlings to protect them from large browsing herbivores (15 each in open and subcanopy sites on sand and fine-textured soil).

\section{Statistical analysis}

Seedlings were monitored monthly for 14 months for growth and survival, starting the first month after transplanting (March 2005) until the end of the experiment in April 2007. The following measurements were recorded monthly for each seedling: height, canopy diameter, change in basal area (based on stem diameters measured with vernier calipers), and the number of branches.

The canopy area was calculated using the following formula for an ellipse (Bronstein and Semendjajew 1991): Cover $=(\mathrm{Pi} / 4)$.canopy1 .canopy2 $(1)$, where canopy 1 and canopy 2 are two perpendicular diameters of the plant as seen from above.

The experiment included time as an independent variable. Repeated measure analysis of variance (ANOVA) was used to test the main factors (soil type, microsite, herbivory) and their interactions on measured plant parameters (height, canopy area, change in stem basal area and number of branches) over time period after testing for normality and homogeneity of the data. ANOVA models significant at 0.05 were used and significantly different treatment means were separated using a Scheffé post-hoc test in Statistica (Statistica 6.1, StatSoft, Inc. 2003). For this paper only the results of heights and canopy areas were considered. The survival of all transplanted seedlings was calculated as the mean number of surviving seedlings per treatment. Seedlings that survived at each recording stage were expressed as a total of the original seedling population planted.

A generalized non-linear model, with a log link function to a Poisson distribution was used to test for differences in number of seedlings that survived 
compared to dead seedlings between treatments (Herbivory and Microsite) for each soil type, since we used count data (Statistica 6.1, StatSoft, Inc. 2003). A survival analysis was done comparing two or more groups in the generalized non linear model module of Statistica, to compare cumulative proportion of seedlings that survived over time.

\section{Results}

Seedling height and canopy cover

At the end of 14 months, the heights of seedlings were significantly greater in the clay soil than the sandy soil (Table 1). Schinus molle seedlings grew significantly taller (Table 1) and had larger canopy areas (Table 2) beneath tree canopies compared to open areas. Position beneath tree canopies had a greater positive effect on the performance of seedlings than other factors. Canopy areas of seedlings, however, did not differ between the two soil types (Table 1).

A significant interaction effect was found between soil types and browsing, but only for seedling height (Table 1). However, height and canopy areas were more negatively affected by large herbivores for seedlings in the shade than those in the open (Tables 3, 4 and Fig. 1). Seedlings in cages were significantly taller and wider than uncaged seedlings but for shaded plants only; no difference was found for caged and uncaged seedlings for plants in the open areas (Fig. 1). The results also indicated the same trend over time for all the interactions. A sudden decline in seedling heights and canopy areas was observed during winter (July-September) for seedlings in the open areas, whether exposed or protected from large herbivores and for both soil types. There was also a greater recovery of canopy areas, in summer (October-January) for unbrowsed seedlings in the shade, compared with those in the open areas for both soil types (Fig. 1).

\section{Seedling survival}

The total mortality of seedlings after 14 months of experiment showed considerable variation across treatments for both soil types. Seedling survival (i.e. mean seedling survival at the end of the experiment) was significantly higher for seedlings beneath tree

Table 2 Results of repeated measure analysis of variance (ANOVA) of Schinus molle heights, and their different interaction effect between soil type, microsite, herbivory and time on transplanted seedling

\begin{tabular}{|c|c|c|c|c|c|c|}
\hline Treatments & SS & Df & MS & $\begin{array}{l}F \text { - } \\
\text { values }\end{array}$ & $\begin{array}{l}P \text { - } \\
\text { values }\end{array}$ & $\begin{array}{l}\text { Significance } \\
\text { level }\end{array}$ \\
\hline (1) Soil type & 43,039 & 1 & 43,039 & 22.556 & $<0.001$ & $* *$ \\
\hline (2) Microsite effect & 271,875 & 1 & 271,875 & 142.485 & $<0.001$ & $* *$ \\
\hline (3) Herbivory effect & 34,683 & 1 & 34,683 & 18.176 & $<0.001$ & $* *$ \\
\hline Soil type $\times$ microsite effect & 1,732 & 1 & 1,732 & 0.907 & 0.342 & NS \\
\hline Soil type $\times$ herbivory effect & 8,367 & 1 & 8,367 & 4.385 & 0.038 & $*$ \\
\hline Microsite effect $\times$ herbivory effect & 27,944 & 1 & 27,944 & 14.645 & $<0.001$ & $* *$ \\
\hline Soil type $\times$ microsite $\times$ herbivory effect & 10,369 & 1 & 10,369 & 5.434 & 0.021 & $*$ \\
\hline (4) Months & 235,749 & 13 & 18,135 & 132.728 & $<0.001$ & $* *$ \\
\hline Months $\times$ Soil type & 12,146 & 13 & 934 & 6.838 & $<0.001$ & $* *$ \\
\hline Months $\times$ microsite effect & 129,919 & 13 & 9,994 & 73.144 & $<0.001$ & $* *$ \\
\hline Months $\times$ herbivory effect & 8,906 & 13 & 685 & 5.014 & $<0.001$ & $* *$ \\
\hline Months $\times$ Soil type $\times$ microsite effect & 7,720 & 13 & 594 & 4.346 & $<0.001$ & $* *$ \\
\hline Months $\times$ Soil type $\times$ herbivory effect & 5,039 & 13 & 388 & 2.837 & $<0.001$ & $* *$ \\
\hline $\begin{array}{l}\text { Months } \times \text { microsite effect } \times \text { herbivory } \\
\text { effect }\end{array}$ & 8,400 & 13 & 646 & 4.729 & $<0.001$ & $* *$ \\
\hline $4 \times 1 \times 2 \times 3$ & 2,740 & 13 & 211 & 1.542 & 0.095 & NS \\
\hline
\end{tabular}

Significance: NS $=$ Non significant; $* P<0.05 ; * * P<0.0001$, with SS $=$ Sum of square; MS $=$ Mean square; Df $=$ Degrees of freedom 
Table 3 Results of repeated measure analysis of variance (ANOVA) of Schinus molle canopy areas, and their different interaction effect between soil type, microsite, herbivory and time on transplanted seedling

\begin{tabular}{|c|c|c|c|c|c|c|}
\hline Treatments & SS & Df & MS & $\begin{array}{l}F- \\
\text { values }\end{array}$ & $\begin{array}{l}P \text { - } \\
\text { values }\end{array}$ & $\begin{array}{l}\text { Significance } \\
\text { level }\end{array}$ \\
\hline (1) Soil type & 199,852 & 1 & 199,852 & 0.8877 & 0.348 & NS \\
\hline (2) Microsite effect & $19,529,103$ & 1 & $19,529,103$ & 86.7464 & $<0.001$ & $* *$ \\
\hline (3) Herbivory effect & $2,718,405$ & 1 & $2,718,405$ & 12.0749 & $<0.001$ & $* *$ \\
\hline Soil type $\times$ microsite effect & 675,016 & 1 & 675,016 & 2.9984 & 0.086 & NS \\
\hline Soil type $\times$ herbivory effect & 111,693 & 1 & 111,693 & 0.4961 & 0.482 & NS \\
\hline Microsite effect $\times$ herbivory effect & $2,582,989$ & 1 & $2,582,989$ & 11.4734 & $<0.001$ & $* *$ \\
\hline Soil type $\times$ microsite effect $\times$ herbivory effect & 152,492 & 1 & 152,492 & 0.6774 & 0.412 & NS \\
\hline (4) Months & $22,852,970$ & 13 & $1,757,921$ & 59.4109 & $<0.001$ & $* *$ \\
\hline Months $\times$ soil type & $4,864,857$ & 13 & 374,220 & 12.6472 & $<0.001$ & $* *$ \\
\hline Months $\times$ microsite effect & $18,172,969$ & 13 & $1,397,921$ & 47.2443 & $<0.001$ & $* *$ \\
\hline Months $\times$ herbivory effect & $2,774,805$ & 13 & 213,447 & 7.2137 & $<0.001$ & $* *$ \\
\hline Months $\times$ soil type $\times$ microsite effect & $1,445,395$ & 13 & 111,184 & 3.7576 & $<0.001$ & $* *$ \\
\hline Months $\times$ soil type $\times$ herbivory effect & $1,183,377$ & 13 & 91,029 & 3.0764 & $<0.001$ & $* *$ \\
\hline Months $\times$ microsite effect $\times$ herbivory effect & $1,875,614$ & 13 & 144,278 & 4.8760 & $<0.001$ & $* *$ \\
\hline $4 \times 1 \times 2 \times 3$ & 972,349 & 13 & 74,796 & 2.5278 & $<0.001$ & $* *$ \\
\hline
\end{tabular}

Significance: NS $=$ Non significant; $* P<0.05 ; * * P<0.0001$, with $\mathrm{SS}=$ Sum of square; MS $=$ Mean square; Df $=$ Degrees of freedom

Table 4 Mean heights $( \pm \mathrm{SE})$ and mean canopy areas $( \pm \mathrm{SE})$ of surviving seedlings of Schinus molle after 14 months protected from large herbivores in sub-canopy microsites and in the open grassland

\begin{tabular}{llccl}
\hline Variables/treatments & $\begin{array}{l}\text { Soil } \\
\text { types }\end{array}$ & $\begin{array}{l}\text { Sub-canopy microsite }+ \text { No herbivory } \\
(\text { Mean } \pm \text { SE) }\end{array}$ & $\begin{array}{l}\text { Open area }+ \text { No herbivory } \\
\text { (Mean } \pm \text { SE) }\end{array}$ & $\begin{array}{l}P \text { - } \\
\text { values }\end{array}$ \\
\hline Heights $(\mathrm{cm})$ & Clay & $65.52 \pm 3.01(15)$ & $24.93 \pm 3.01(15)$ & $<0.001$ \\
Canopy areas $\left(\mathrm{cm}^{2}\right)$ & Clay & $434.68 \pm 32.74(15)$ & $161.66 \pm 32.74(15)$ & $<0.001$ \\
Heights $(\mathrm{cm})$ & Sandy & $43.94 \pm 3.01(15)$ & $17.34 \pm 3.01(15)$ & $<0.001$ \\
Canopy areas $\left(\mathrm{cm}^{2}\right)$ & Sandy & $417.59 \pm 32.74(15)$ & $102.50 \pm 32.74(15)$ & $<0.001$ \\
\hline
\end{tabular}

$P$-values obtained through Scheffé post-hoc tests

canopies than for those in the open areas, on both soil types (Tables 5, 6 and Fig. 2). There were significant differences in survival of seedlings in subcanopy and open sites. Soil type and herbivory had no significant influence on survival (Table 6 and Fig. 2). At the end of the experiment, all of the seedlings in the open area, whether exposed to or protected from large herbivores, had died and only seedlings beneath tree canopies remained alive. In contrast, beneath tree canopies, survival of seedlings protected from large herbivores was greater than for seedlings exposed to large herbivores on both soil types, but significant only for seedlings on the clay soil (Tables 5 and 6).
Although seedling mortality in the sandy soil began later than in fine soil, mortality was also faster in the sandy soil than in the clay soil where seedling numbers declined more gradually (Fig. 2a). Mortality occurred more quickly for seedlings in the open area, whether exposed to or protected from large herbivores, than for seedlings beneath tree canopies (Figs. 1, 2b). The results also show that seedling mortality in the open areas started in winter with a fast decrease until the end of the experiment when the all seedlings were dead; in contrast, below tree canopies mortality was low and gradual (Fig. 2b; Table 7). 

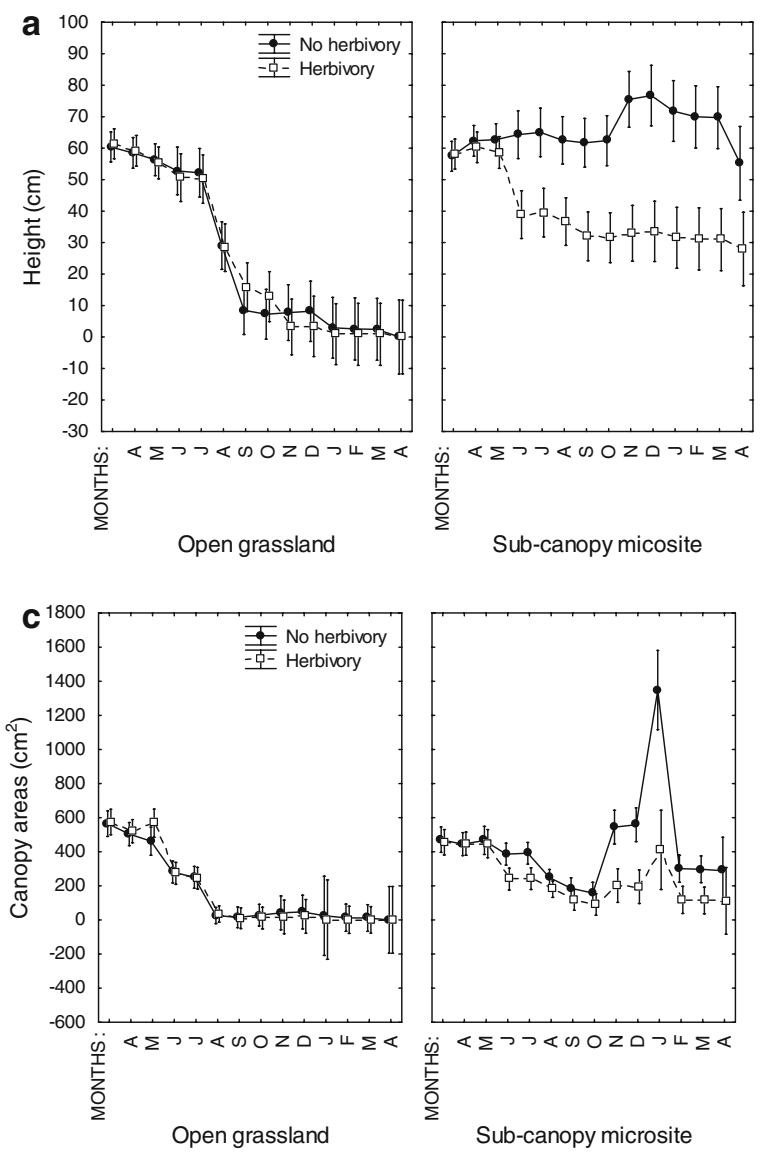

Fig. 1 Interaction effect of months, shading and soil type on mean heights and mean canopy areas of Schinus molle. Solid line $=$ protected from large herbivory, and dotted line = exposed to herbivory. The graph (a) heights for clay soil,
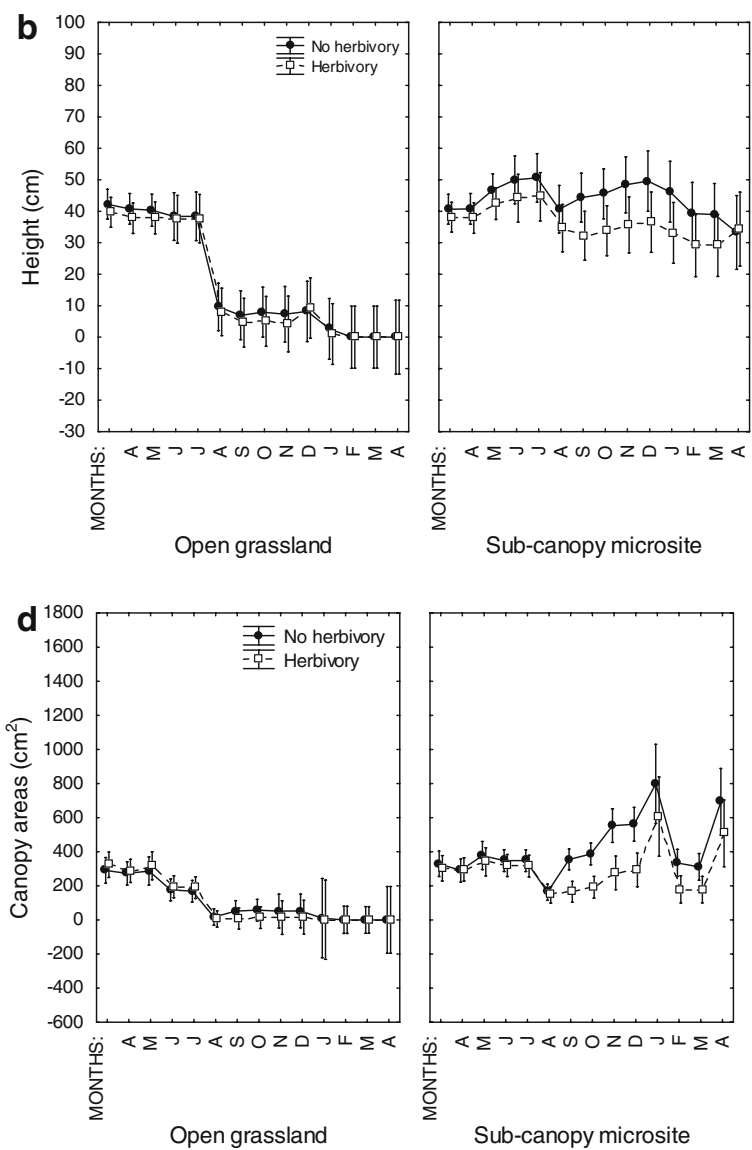

(b) heights for sandy soil, (c) canopy areas for clay soil and (d) canopy areas for sandy soil. Vertical bars show standard deviations from the mean

Table 5 Mean heights $( \pm \mathrm{SE})$ and mean canopy areas $( \pm \mathrm{SE})$ of surviving seedlings of Schinus molle after 14 months exposed to or protected from large herbivores in sub-canopy microsites

\begin{tabular}{llcrc}
\hline Variables/treatments & Soil types & $\begin{array}{l}\text { Herbivory }+ \text { sub-canopy } \\
\text { microsite }(\text { Mean } \pm \text { SE) }\end{array}$ & No herbivory + sub-canopy microsite $($ Mean \pm SE) & $P$-values \\
\hline Heights $(\mathrm{cm})$ & Clay & $38.85 \pm 3.01(15)$ & $65.52 \pm 3.01(15)$ & $<0.001$ \\
Canopy areas $\left(\mathrm{cm}^{2}\right)$ & Clay & $240.45 \pm 32.74(15)$ & $434.68 \pm 32.74(15)$ & $<0.001$ \\
Heights $(\mathrm{cm})$ & Sandy & $36.12 \pm 3.01(15)$ & $43.94 \pm 3.01(15)$ & 0.263 \\
Canopy areas $\left(\mathrm{cm}^{2}\right)$ & Sandy & $294.09 \pm 32.74(15)$ & $417.59 \pm 32.74(15)$ & 0.144 \\
\hline
\end{tabular}

$P$-values obtained through Scheffé post-hoc tests

\section{Discussion}

Microsite effect

The results clearly indicate that sub-canopy microsite, protection of seedlings from large herbivores and fine-texture soil; together improve $S$. molle seedling performance in semi arid savanna. However, canopy cover of large Acacia trees seems to be the most important factor determining the survival of $S$. molle seedlings despite the fact that the species is known to be drought tolerant (Howard and Minnich 1989). The 
Table 6 Log link function to a Poisson distribution of the mean $( \pm \mathrm{SE})$ number of seedlings of Schinus molle that survived at 14 months for different treatment interactions $\left(\chi^{2}=0.000 ; P=\mathrm{NA}\right)$

\begin{tabular}{llll}
\hline $\begin{array}{l}\text { Soil } \\
\text { types }\end{array}$ & $\begin{array}{l}\text { Microsite } \\
\text { effect }\end{array}$ & $\begin{array}{l}\text { Herbivory } \\
\text { effect }\end{array}$ & $\begin{array}{l}\text { Mean } \\
\text { percentage } \\
\pm \text { SE }\end{array}$ \\
\hline Clay & Open area & No herbivory & $0(15)$ \\
Clay & Open area & Herbivory & $0(15)$ \\
Clay & Sub-canopy & No herbivory & $0.73 \pm 0.12(15)$ \\
Clay & Sub-canopy & Herbivory & $0.47 \pm 0.13(15)$ \\
Sandy & Open area & No herbivory & $0(15)$ \\
Sandy & Open area & Herbivory & $0(15)$ \\
Sandy & Sub-canopy & No herbivory & $0.60 \pm 0.13(15)$ \\
Sandy & Sub-canopy & Herbivory & $0.67 \pm 0.13(15)$ \\
\hline
\end{tabular}
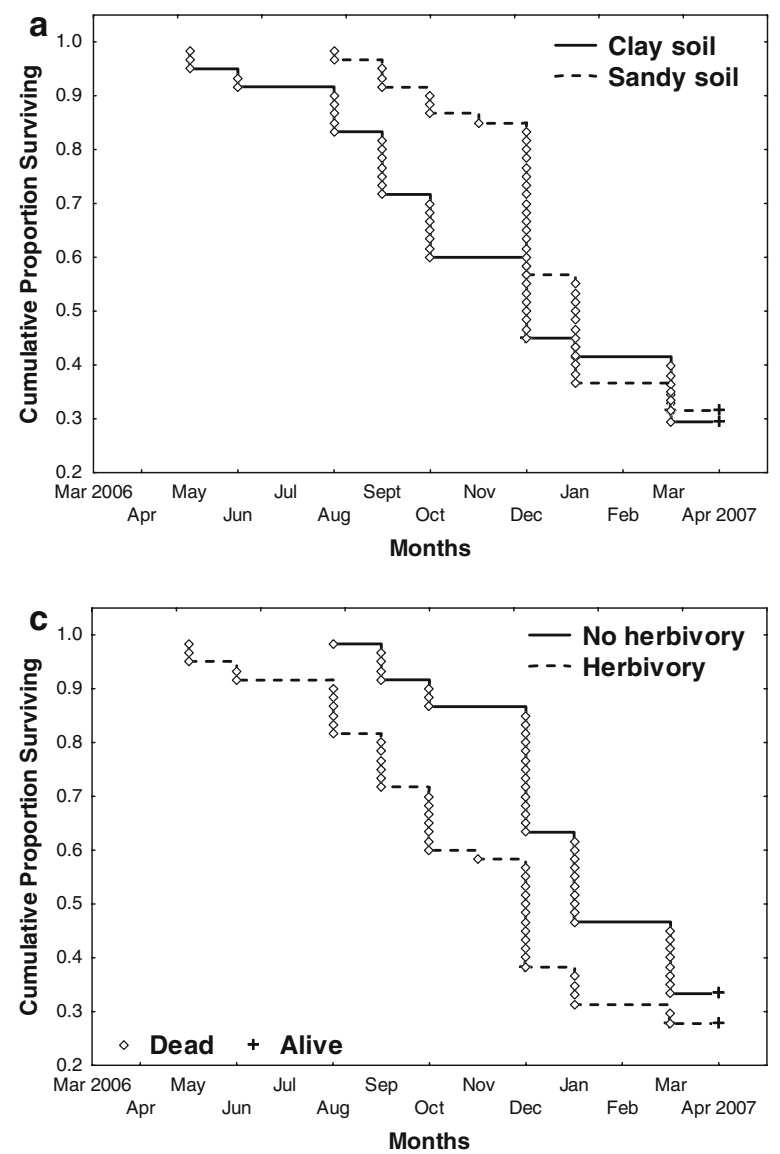

Fig. 2 Cumulative proportion of Schinus molle seedling that survival over time. The graphs show: (a) clay soil vs. sandy soil; (b) open grassland vs. sub-canopy microsite; (c) protected results showed that $S$. molle seedlings grew better in the subcanopy sites than in the open grassland and suggested that those facilitation processes occur across both clay and sandy soil. The good performance of seedlings underneath of tree canopies could be associated with the microclimate condition created by the canopy underneath of Acacia trees, which often act as a nurse plant for fleshy-fruited shrubs in semi arid savannas (Milton et al. 2007).

Tree and shrub canopies buffer temperature changes beneath them, so that the difference between minimum and maximum temperatures is less below tree canopies than in open grassland (Belsky et al. 1989). During winter, the minimum temperatures remain higher below tree and shrub canopies than in the open (Davies et al. 2007; Drezner 2007). Seedlings in the open areas

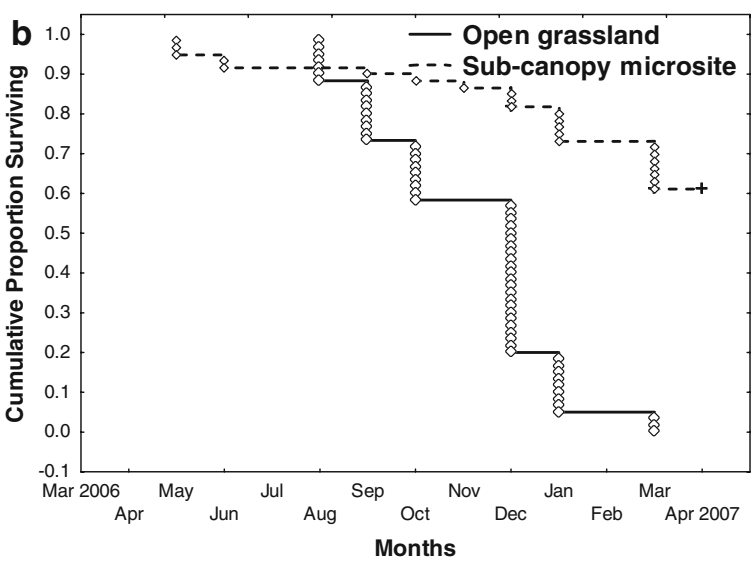

from large herbivory vs. exposed to large herbivory. The cross (+) proportion of seedling that survived and, (0) no seedling survived 
Table 7 Descriptive statistics of survival analysis for each group

\begin{tabular}{lrrrrr}
\hline Treatment groups & Dead & $\begin{array}{l}\text { Percent } \\
\text { dead }(\%)\end{array}$ & $\begin{array}{c}\text { Alive } \\
\text { Percent } \\
\text { alive }(\%)\end{array}$ & Total $N$ \\
\hline Clay soil & 42 & 70.00 & 18 & 30.00 & 60 \\
Sandy soil & 41 & 68.33 & 19 & 31.67 & 60 \\
Open area & 60 & 100.00 & 0 & 0.00 & 60 \\
Sub-canopy & 23 & 38.33 & 37 & 61.67 & 60 \\
No herbivory & 40 & 66.67 & 20 & 33.33 & 60 \\
Herbivory & 43 & 71.67 & 17 & 28.33 & 60 \\
\hline
\end{tabular}

Clay soil vs. sandy soil $(P=0.08 ; z=-1.74)$; Open grassland vs. tree sub-canopy $(P<0.001 ; z=-6.73)$; Herbivores vs. No herbivores $(P<0.05 ; z=2.81)$

may experience more frequent and more severe frosts than their counterparts beneath tree canopies (Shumway 2000). In summer the shading effects of the canopy might decrease light penetration, reduce of solar radiation and lower soil surface temperature, thereby reducing desiccation and increasing higher relative humidity, which potentially can enhance $S$. molle seedling establishment and growth (Belsky 1994; Scholes and Archer 1997). This is also consistent with argument that light reduction below pioneer trees could be responsible for the unusually high success of tree seedlings that have been observed to recruit near established trees in the grasslands (Scholes and Archer 1997; Weltzin and McPherson 1999; Van Auken 2000; Teague et al. 2001).

Although most seedling shoot dieback began during the winter, suggesting that extreme cold or frost may be implicated in the mortality of $S$. molle seedlings in open sites, further experiments are required to discriminate between the effects of temperature amelioration, and of reduced radiation or transpiration rates, on seedling survival.

It is also possible that competition from grass may be the cause of sudden decline of seedling performance in the open areas. Studies in old field grasslands have shown that grass competition could reduce growth and survival of woody plant seedlings in a grass dominant environment (Iponga et al. 2005). However, given that winters are dry and grasses generally dormant in winter, the competition hypothesis seems less plausible than the facilitation hypothesis in explaining mortality patterns. Because this experiment did not measure competition and physical factors directly, it is not clear which one of those may have the more negative effect on seedling performance in the open areas.

The effect of large herbivores

The results showed that seedlings exposed to large herbivores were significantly shorter than those protected from large herbivores for both soil types, beneath tree canopies and in the open, and that this effect was more marked on fine-textured soils and beneath tree canopies. Herbivores are well known to reduce seedling performance and cause plant mortality (Pitt et al. 1998; Iponga et al. 2005). Seedlings exposed to large herbivores experience more trampling and browsing damage in the shade, because those microsites are preferentially used by large herbivores for resting and browsing food (Belsky et al. 1989; Dean et al. 1999). However, it was not possible to tell which species of herbivores caused more damage to $S$. molle seedling.

Seedlings in the open areas exposed to or protected from large herbivores did not differ significantly in size. The reason is probably that herbivore damage was obscured by other sources of variation among seedlings such as frosting caused by lower temperature during winter season, or drought in summer. The ability of introduced plants to establish and spread may depend not only on the structure of the resident biotic community, but also the local abiotic conditions or their joint effects (Mitchell et al. 2003; DeWalt et al. 2004). These results contrast with several studies that have indicated a positive relationship between grazing intensity and degree of invasion in grassy woodland systems (Prober and Thiele 1995; Abensperg-traun et al. 1998) and have suggested that removal of stock is a common management approach for reducing the rate of invasion in those ecosystems (Elix and Lambert 1997). Higher densities of large game on the clay substrate may have contributed to lower seedling performance, which, in turn, may have contributed to lower the risk of $S$. molle invasion in those areas. This again indicates that herbivores can exert considerable control over $S$. molle seedling performance beneath tree canopy.

How do substrate textures affect seedling performance?

Particle size and organic matter content in the soil, affects water holding capacity, aeration, resistance to 
root penetration, and nutrient availability (Freitas and Mooney 1996; Reich et al. 1997), all of which have been shown to influence seedling survival (Peters 2004). Sandy substrates in the semi-arid and arid parts of South Africa are nutrient poor relative to finer-textured soils (Milton et al. 1992). Soil phosphorous and other nutrients adhere to clay particles and are less mobile in clay than in sand (Allcock 2002). Nutrient-enriched patches beneath trees would therefore be more persistent on clay than on sand, and possibly more prone to alien invasion for this reason (Vinton and Burke 1995).

Moreover, S. molle is probably sensitive to water availability at the establishment stage, and finetexture soils have better water-holding capacity than coarse sandy soil (Nambiar 1979; Gordon et al 1989; Freitas and Mooney 1996; Reich et al. 1997). The ability of newly planted seedlings to perform well can be related to their water status (Mana-Petite and Muñoz-Rueda 2005). The rainfall in Kimberley area is extremely variable, both in time and in spatial distribution; it usually peaks in the late summer months with March and April being the wettest months (South African Weather Bureau 2007). There is a distinct arid period during winter and humid period during summer months. The sudden drop of seedling performance observed in winter in the open area during this experiment could be associated to post planting water and nutrient stress due to the lack of water in winter; which may cause lack of continuity between soil and roots immediately after planting, and increase the time needed to produce adequate amounts of new roots to resume water and nutrients uptake. Grossnickle (2000) found that, until the root system has grown sufficiently to offset transpiration loss with water uptake, seedlings may continue to suffer water stress and exhibit high mortality rates.

Interaction effects

Significant three-way interactions between soil types, microsite and herbivory effect were found for heights, but not canopy areas, of seedlings. This significant three-way interaction was probably due to the interaction between microsite and herbivory effect on seedling performance, where seedlings in the clay soil experience more herbivory damage than the sandy soil for seedlings beneath of tree canopies.
This suggested that seasonal and inter-annual fluctuations in physical conditions may influence seedling performance in semi-arid savanna. Tree recruitment in semi-arid savannas occurs in occasional favourable spells (Higgins et al. 2000; Jeltsch et al. 2000) that maintain tree populations in environments generally unfavourable for seedling establishment and survival, but favourable for adult plants.

Large Acacia trees in semi-arid savanna are focal points for animal activity (Dean et al. 1999; Radford et al. 2001) because they supply nest sites for birds, shade and food resources for animals. Soil beneath trees is enriched by fallen nests, bird droppings and dung deposition by large herbivores, (Dean et al. 1999), so that plants growing beneath tree canopies are often more nutritious than plants in surrounding habitat (Belsky et al. 1993). Productive, nutritious plants tend to attract more herbivorous animals to patches near trees, reinforcing nutrient enrichment in those areas, but may also cause seedling mortality indirectly due to trampling effects. Our results support the notion that large trees may elevate plant nutrient concentrations beneath their canopies improving productivity of subcanopy plants, a phenomenon reported in other African savannas (Roos and Alsopp 1997).

\section{Survival}

Although there was a considerable variation of seedling survival across treatment and sites after transplanting of $S$. molle seedlings, survival was always higher for seedlings in tree sub-canopy microsites than those in the open habitats for both soil types. Large A. tortilis trees appear to have the greatest influence on $S$. molle survival in semi-arid savannas with frosty winters, and thus facilitate the invasion of this species into savanna. It is therefore unlikely that $S$. molle will invade treeless ecosystems or habitats that are subject to frost and drought. However, management-induced bush thickening or invasion of these savannas by trees (such as Prosopis sp.) that establish in open microsites could promote $S$. molle invasion in grassland (Siemann and Rogers 2003).

\section{Conclusion}

This study demonstrated that the control of invasion of $S$. molle in semi-arid savannas is complex and may 
simultaneously depend on multiple biotic and abiotic variables. The results show that height and canopy area decreased in the winter in the open areas but not under trees canopies and that herbivory caused height and canopy area reductions beneath tree canopies but not in the open area where all seedlings died. Soil type did not affect these general patterns. We conclude that physical factors (probably frost) damage seedlings in the open, whereas biotic factors (probably herbivory) damage seedlings beneath canopies. Under the current climate and vegetation, no recruitment of $S$. molle is likely to occur in open areas in semi-arid savannas at altitudes of $1,000 \mathrm{~m}$ or more above sea level. The possibility of $S$. molle plants being facilitated by tree canopies in semi-arid savanna has to be taken into consideration when assessing the probability for further invasion. Our study also indicated that large herbivores could control the distribution of this species and that $S$. molle is less likely to spread on sandy substrates. However, before using these results to make any inferences to management of the species as an invader, it is important to note that our experiment tested individual performance, and thus there can only be limited interference to population-level response.

Acknowledgement We acknowledge financial support from the DST-NRF Centre of Excellence for Invasion Biology.

\section{References}

Abensperg-traun M, Atkins L, Hobbs R, Steven D (1998) Exotic plant invasion and understory species richness: a comparison of two types of eucalypt woodland in agricultural Western Australia. Pac Cons Biol 4:21-32

Allcock KG (2002) Effects of phosphorus on growth and competitive interactions of native and introduced species found in white box woodlands. Austral Ecol 27:638-646

Belsky AJ (1994) Influences of trees on savanna productivity: tests of shade, nutrients and tree-grass competition. Ecology 75:922-932

Belsky AJ, Amundson RG, Duxbury JM, Riha SJ, Ali AR, Mwonga SM (1989) The effects of trees on their physical, chemical, and biological environments in a semiarid savanna in Kenya. J appl Ecol 26:1005-1024

Belsky AJ, Mwonga SM, Amundson RG, Duxbury JM, Ali AR (1993) Comparative effects of isolated trees on their undercanopy environments in high- and low-rainfall savannas. J appl Ecol 30:143-155

Bronstein IN, Semendjajew KA (1991) Taschenbuch der Mathematik, 25th edn. B.G. Teubner Verlagsgesellschaft, Stuttgart
Callaway RM (1995) Positive interactions among plants. Bot Rev 61:306-349

Canham CD (1989) Different responses to gaps among shade tolerant tree species. Ecology 70:548-550

Davies KW, Bates JD, Miller RF (2007) The influence of Artemesia tridentata ssp. wyomingensis on microsite and herbaceous vegetation heterogeneity. J Arid Environ 69:441-457

Dean WRJ, Milton SJ (2000) Directed dispersal of Opuntia species in the Karoo, South Africa: are crows the responsible agents? J Arid Environ 45:305-314

Dean WRJ, Milton SJ, Jeltsch F (1999) large trees, fertile islands and birds in arid savanna. J Arid Environ 40:61-78

DeWalt SJ, Denslow JS, Ickes K (2004) Natural-enemy release facilitates habitat expansion of the invasive tropical shrub Clidemia hirta. Ecology 85:471-483

Drezner TD (2007) An analysis of winter temperature and dew point under the canopy of a common Sonoran Desert nurse and implications for positive plant interactions. J Arid Environ 69:554-568

Elix J, Lambert J (1997) More than just the odd tree: incentives and barriers to rural woodland conservation. Environment Australia, Canberra

Flores J, Enrique J (2003) Are nurse-protégé interactions more common among plants from arid environments? J Veg Sci 14:911-916

Freitas H, Mooney H (1996) Effects of water stress and soil texture on the performance of 2 Bromus hordeaceus from sandstone and serpentine soils. Acta Oecol 17:307-317

Gordon DR, Welker JM, Menke JW, Rice KJ (1989) Competition for soil water between annual plants and blue oak seedlings. Oecologia 79:533-541

Grossnickle SC (2000) Ecophysiology of Northern Spruce species. The performance of planted seedlings. NCRCNRC Research Press, Ottawa

Higgins SI, Bond WJ, Trollope WSW (2000) Fire, resprouting and variability: a recipe for grass-tree coexistence in savanna. J Ecol 88:213-229

Hoffmann JH, Moran VC (1998) The population dynamics of an introduced tree, Sesbania punicea, in South Africa, in response to long-term damage caused by different combinations of three species of biological control agents. Oecologia 114:343-348

Howard LF, Minnich RA (1989) The introduction and naturalization of Schinus molle (Pepper Tree) in Riverside, California. Landsc Urban Plan 18:77-95

Iponga DM, Krug CB, Milton SJ (2005) Competition and herbivory influence growth and survival of shrubs on old fields: implication for restoration of renosterveld shrubland. J Veg Sci 16:685-692

Iponga DM, Milton SJ, Richardson DM (2008) Superiority in competition for light: a crucial attribute defining the impact of the invasive alien tree Schinus molle (Peruvian pepper tree) in South Africa. J Arid Environ. doi: 10.1016/j.jaridenv.2007.10.001

Jeltsch F, Weber GE, Grimm V (2000) Ecological buffering mechanisms in savannas: a unifying theory of long-term tree grass coexistence. Plant Ecol 161:161-171

Jordano P, Herrera CM (1995) Shuffling the offspring: uncoupling and spatial discordance of multiple stages in vertebrate seed dispersal. Ecoscience 2:230-237 
Mana-Petite A, Muñoz-Rueda A (2005) Effect of cold storage treatments and transplanting stress on gas exchange, chlorophyll fluorescence and survival under water limiting conditions of Pinus radiata stock-types. Eur J For Res 124:73-82

Milton SJ, Dean WRJ, Marincowitz CP (1992) Preferential utilization of pans by springbok (Antidorcas marsupialis). J Grassl Soc Sth Afr 55:259-266

Milton SJ, Wilson JRU, Richardson DM, Seymour CL, Dean WRJ, Iponga DM, Procheş Ş (2007) Invasive alien plants infiltrate bird-mediated shrub nucleation processes in arid savanna. J Ecol 95:648-661

Mitchell CE, Reich PB, Tilman D, Groth JV (2003) Effects of elevated $\mathrm{CO} 2$, nitrogen deposition, and decreased species diversity on foliar fungal plant disease. Global Change Biol 9:438-451

Mucina L, Rutherford MC, Powrie LW (eds) (2006) Vegetation map of South Africa, Lesotho and Swaziland, 1/1000 000 scale sheet map. South Africa National Biodiversity institute, Pretoria

Nambiar EKS, Bowen GD, Sands R (1979) Root regeneration and plant water status of Pinus radiata D. Don seedlings transplanted to different soil temperatures. J Exp Bot 30:1119-1131

Nel JL, Richardson DM, Rouget M, Mgidi T, Mdzeke N, Le Maitre DC, van Wilgen BW, Schonegevel L, Henderson L, Neser S (2004) A proposed classification of invasive alien plant species in South Africa: towards prioritising species and areas for management action. S Afr J Sci 100:53-64

Peters DPC (2004) Selection of models of invasive species dynamics. Weed Technol 18:1236-1239

Pitt MD, Newman RF, Youwe PL, Wikeem BM, Quinton DA (1998) Using a grazing pressure index to predict cattle damage of regenerating tree saplings. J Range Manage 51:417-422

Prober SM, Thiele KR (1995) Conservation of the grassy white box woodlands: relative contributions of size and disturbance to floristic composition and diversity of remnants. Aust J Bot 43:349-366

Radford IJ, Nicholas DM, Brown JR (2001) Impact of prescribed burning on Acacia nilotica seed banks and seedlings in the Astrebla grasslands of northern Australia. J Arid Environ 49:795-807

Reich PB, Grigal DF, Aber JD, Gower ST (1997) Nitrogen mineralization and productivity in 50 hardwood and conifer stands on diverse soils. Ecology 78:335-347

Richardson DM, Bond WJ, Dean WRJ, Higgins SI, Midgley GF, Milton SJ, Powrie L, Rutherford MC, Samways MJ,
Schulze RE (2000) Invasive alien organisms and global change: a South African perspective. In: Mooney HA, Hobbs RJ (eds) Invasive species in a changing world. Island Press, Washington DC, pp 303-349

Roos PC, Allsopp N (1997) Soil nutrient ecology associated with Acacia sieberana at different tree densities in a South African savanna. Afr J Range Forage Sci 14:39-44

Rouget M, Richardson DM, Nel JL, Le Maitre DC, Egoh B, Mgidi T (2004) Mapping the potential spread of major plant invaders in South Africa using climatic suitability. Diversity Distrib 10:475-484

Russell SK, Schupp EW (1998) Effects of microhabitat patchiness on patterns of seed dispersal and seed predation of Cercocarpus ledifolius (Rosaceae). Oikos 81:434-443

Scholes RJ, Archer SR (1997) Tree-grass interactions in savannas. Annu Rev Ecol Evol Syst 28:517-544

Shumway SW (2000) Facilitative effects of a sand dune shrub on species growing beneath the shrub canopy. Oecologia 124:138-148

Siemann E, Rogers WE (2003) Changes in light and nitrogen availability under pioneer trees may indirectly facilitate tree invasions of grasslands. J Ecol 91:923-931

Silva SI, Bozinovic F, Jaksic F (2005) Frugivory and seed dispersal by foxes in relation to mammalian prey abundance in a semi arid thornscrub. Austral Ecol 30:739-746

South African Weather service http://www.weathersa.co.za/ Climat/Climstats/KimberleyStats.jsp

Spottiswoode CN (2005) Behavioural ecology and tropical lifehistories in African birds. $\mathrm{PhD}$ thesis, University of Cambridge, UK

StatSoft, Inc. (2003) STATISTICA (data analysis software system), version 6. www.statsoft.com

Teague WR, Dowhower SL, Whisenant SG, Flores-Ancira E (2001) Mesquite and grass interference with establishing redberry juniper seedlings. J Range Manage 54:680-684

Van Auken OW (2000) Shrub invasions of North American semiarid grasslands. Annu Rev Ecol Evol S 31:197-215

Verdú M, García-Fayos P (1996) Nucleation processes in a Mediterranean bird-dispersed plant. Funct Ecol 10:275280

Vinton MA, Burke IC (1995) Interactions between individual plant species and soil nutrient status in shortgrass steppe. Ecology 76:1116-1134

Weltzin JF, McPherson GR (1999) Facilitation of conspecific seedling recruitment and shifts in temperate savanna ecotones. Ecol Monogr 69:513-534 